\title{
Beyond Hollywood: Transmedia Strategy for Niche Audiences
}

Cameron Cliff

DOI: https://doi.org/10.17230/9789587206289ch12

\section{Introduction}

Recent technological and cultural developments, centred around the popularisation of the Internet, have led to significant and ongoing changes in how audiences are interacting with and experiencing stories (Jenkins, 2006).

There is no more central issue in media and communications studies today than the proposition that we are in the middle of a rapid process of change that is seeing established or 'old' media being challenged for primacy in audiences' and users' attention by new modes and types of production, dissemination and display (Cunningham, Silver, \& McDonnell, 2010, p. 119).

It is in this landscape that the practice of transmedia storytelling has enjoyed a tumultuous place of prominence across media and cultural studies, advertising and marketing research (Fast \& Örnebring, 2015).

When scholars and practitioners discuss transmedia storytelling, ${ }^{1}$ they inevitably find themselves referencing worlds created by large media conglomerates. High budget 'Hollywood' spectacles like Star Wars, The Marvel Cinematic Universe and Game of Thrones are the most visible

* Bachelor of Film and Screen Media, Writing and Producing from Griffith University, Australia; Bachelor of Creative Industries, Film \& Transmedia from Queensland University of Technology, Australia; Ph.D. in Communication and Media Studies from Queensland University of Technology. Creative Producer \& Strategy Consultant; Researcher \& Industry Consultant, Queensland University of Technology. Email: cam@cliffhangercreative.com

1 Referring to a timeless practice dating back before the dark ages (Evans, 2011), transmedia storytelling in a modern context is based on the concept of transmedia intertextuality (Kinder, 1991). Transmedia intertextuality describes the way in which large media conglomerates expand successful media franchises by creating new forms of interaction and storytelling such as spin-off series, video games and merchandise. Coined by Jenkins (2003), the term transmedia storytelling refers to multiple delivery platforms (such as films, games or books) providing separate but interlinked narratives within the same narrative world. "For example, in The Matrix franchise, key bits of information are conveyed through three live action films, a series of animated shorts, two collections of comic book stories, and several video games. There is no one single source or ur-text where one can turn to gain all of the information needed to comprehend the Matrix universe" (Jenkins, 2007). Transmedia storytelling then refers to how separate but interlinked narrative modes are used to construct "a whole that is greater than the sum of its parts" (Evans, 2011, p. 30). 
transmedia stories (Hadas, 2014). They form a large part of the practice's developmental history (Johnson, 2012) and a large portion of transmedia practice in the digital age has emerged from the marketing and narrative practice of media franchises owned by large conglomerates (Livingstone, McKenny, \& Flanagan, 2017). However, beyond the evergreen pastures of conglomerate owned narratives, independent storytellers have been using their own, alternate forms of transmedia storytelling to create successful, meaningful, and sustainable projects. There are those who argue that transmedia storytelling is potentially better for small businesses as they rely on innovative content to differentiate themselves from larger competitors (Bressler, 2012; Deuze, 2010).

This paper puts forward an alternate way of analysing transmedia projects, using an interdisciplinary toolkit based on business strategy theory to cut through some of the problems of transmedia research. In doing so it puts forward a framework for analysing transmedia strategies. Using this framework, it also conducts a case analysis of a leading independent project, Sofia's Diary. Originally a Portuguese narrative about the daily trials of a teenage school girl, Sofia's Diary was repackaged and remade in over 30 different territories around the world. Analysing it with these frameworks demonstrates an alternate, successful strategy for engaging specific niche audiences, one that is reliant upon fostering a sense of social connection and showcasing a deep understanding of specific audiences through the way that stories are told.

\section{The Trouble with Transmedia Storytelling \& Transmedia Literature}

Transmedia storytelling has many documented benefits for practitioners; enhanced longevity and commercial success of story worlds (Hardy, 2011), greater word of mouth amongst global audiences (Sinnreich, 2007), higher audience satisfaction (Long, 2007) and servicing a large variety of audience members with catered content (Smith, 2009). It follows over the last decade of placing consumer communities and meaningful interaction at the centre of successful strategy within most industries (Whitler \& Morgan, 2017). However, "the nature and breadth of transmedia practice has been obscured because investigations have been specific to certain industries, artistic sectors and forms" (Dena, 2014, p. 4). What may be 
the greatest irony of transmedia research is that, founded upon a philosophy of holistic and synergistic approaches to storytelling, the field lacks a holistic and synergistic approach to understanding transmedia that is directly relevant to practice.

Reviewing the existing literature, it is clear that most applications and investigations of transmedia storytelling are clouded by 'semantic chaos'; a blurring of both meaning and application as a multitude of different people with different agendas adapt transmedia storytelling for their own means (Scolari, 2009). Figure 1, overleaf, illustrates this chaos. It shows the separate silos of research pushing and pulling on transmedia storytelling.

Figure 1. Semantic Chaos in Transmedia Storytelling

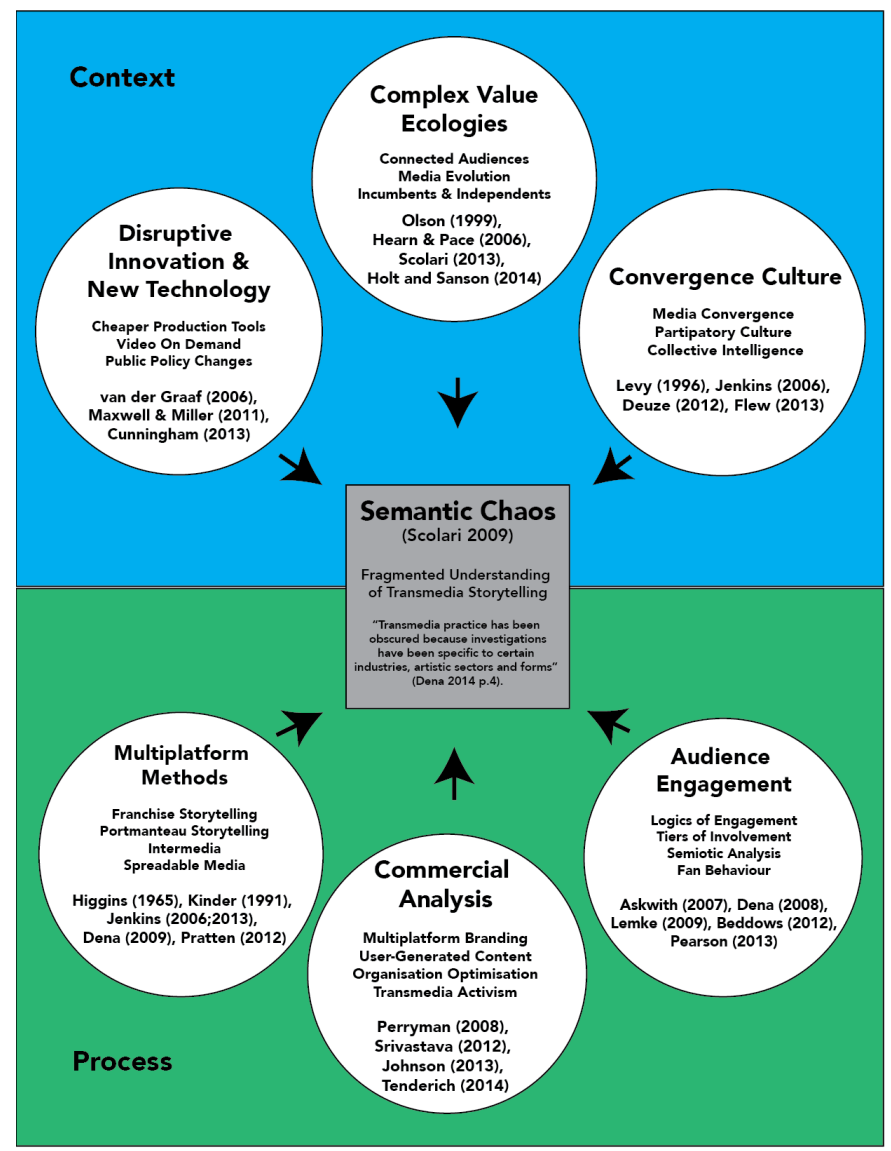

Source: Cliff (2017, p. 5). 
As Figure 1 demonstrates, transmedia storytelling is a concept that stands at the intersection of many competing methods and ontological perspectives. ${ }^{2}$ This is no more evident than in the perceived need of most scholars to clarify their definition of transmedia storytelling before conducting any in depth analysis. In doing so, understanding the application of transmedia storytelling to practice is often confused or fractured by competing ideas, as multiple people from different disciplines adopt or adapt these definitions to suit their own ends (Jenkins, 2012). In practice, this has led to leading practitioners like the late Brian Clark branding transmedia storytelling a lie, lamenting the evolution of transmedia storytelling from an experimental, emerging practice to a blurred concept with unfocussed and seemingly unending applicability (Clark, 2012).

Reviewing the literature, however, there is a solution to this chaos. Discussions of transmedia storytelling focus on the practice as a "process rather than an end result", a strategic way of storytelling (Fast \& Örnebring, 2015, p. 4). Yet, despite leading transmedia scholars such as Jenkins (2006), Scolari (2009), Norrington (2010) and Holt and Sanson (2014) all referring to transmedia storytelling as a strategy, there are almost no works that analyse transmedia storytelling from a strategic perspective. ${ }^{3}$ This paper takes up that challenge.

\section{The Strategic Perspective}

Strategy is what a company does differently to its rivals, the activities that it undertakes that give it a unique position in a marketplace and a sustainable competitive advantage (Magretta, 2012). As this section shows, not only is it directly relevant to the concept of transmedia storytelling, but there are already frameworks that have existed for decades in the sphere of strategic research that can be used to understand the benefits and application of transmedia in practice.

2 See Appendix A for a list of similar definitions as people explore this space.

3 One article does use strategic theory to conduct a resource-based analysis of the Taiwanese television industry. Hsu and Shih (2013) recommend a shift towards the use of transmedia storytelling by public broadcasters as, in their view, it provides them with more sustainable production pathways. Their work demonstrates the benefits of applying strategic theory to transmedia storytelling and that media conglomerates using a strategic approach are likely to be effective in leveraging their resources to help differentiate their narrative experiences. However, their article does not provide a framework for the analysis of transmedia storytelling as strategy. 
When leading scholars such as Jenkins (2006), Dena (2009) and Scolari (2013) investigate the transmedia concept, they do so by centring their analysis on the entertainment market. They analyse how storytelling companies create worlds that leverage changes to audience behaviour within that market. For example, Jenkins (2006) grounds the rise of transmedia storytelling today on storytellers aligning themselves with their audiences; creating experiences that appeal to a modern audience empowered by digital technology (convergence) to work together (collective intelligence), share and participate in narratives that they enjoy (participatory culture). This focus upon the audience and leveraging changes within the marketplace reflects what is known in business thinking as the efficiency paradigm.

The efficiency paradigm proposes that the actions of firms determine industry structure, that dominant firms are those who are more efficient than their rivals (Rosenbaum, 1998). By knowing a market better (Porter, 1991), being more efficient at generating value for that market and its customers (Rosenbaum, 1998) and/or avoiding competition altogether (Kim \& Mauborgne, 2013) a firm succeeds and industries develop. Analysing transmedia storytelling strategy under this paradigm means analysing how storytelling firms differentiate themselves from one another by understanding their market (market dynamics, competitive environment and consumer behaviours) and then aligning their resources accordingly to achieve competitive advantage (Collis \& Montgomery, 1998). ${ }^{4}$

Concepts developed by Michael Porter, a seminal business scholar in competitive advantage, have direct relevance to transmedia storytelling. In particular, Porter (1996) links sustainable success to "combining activities" and amplifying the value produced by a business" (p. 73), a process that is also the guiding ethos of transmedia producers who seek to create a "whole that is bigger than the sum of its parts" (Falzon, 2012, p. 926). It is for this reason that we can use competitive advantage theory

4 Competitive advantage is a vital consideration within this view of strategy, as it focusses analysis upon the different ways that companies leverage their resources to succeed (Hamel \& Prahalad, 1989). Hamel and Prahalad (1989) epitomise this perspective, arguing that a company can establish a vision for success based on a desired position within a market and then stretch their resources to achieve that goal (strategic intent). However, an alternate, resource based view also exists within this paradigm in which a firm is seen as making the most profit by optimising available resources to meet market demand (Barney \& Clark, 2007). 
to coordinate the disparate silos of transmedia research (media culture, semiotics, marketing, branding, narrative theory etc.) when analysing transmedia projects.

\section{Step 1: Context and Generic Strategies}

The first step in separating different types of successful transmedia strategies is a consideration of context and the generic strategic response that a company develops as a response to that context. Regardless of industry, developing sustainable and competitive strategies is directly related to how a company acts to take advantage of the context in which they operate (Aaker, 1998). Porter (1991) argues that an individual strategy is then shaped by a company's capabilities and the goals of each firm within that context.

Adapting these concepts to the sphere of transmedia storytelling, this is most evident in how scholars discuss Hollywood productions. A pervasive discussion within transmedia and broader media culture scholarship is that large, dominant incumbent media producers, such as Hollywood studios, and small independent and/or emerging producers use transmedia storytelling to compete in a vast, expanding and increasingly crowded global video market.

Many scholars and critics have noted that media ownership is controlled by an increasingly small number of mega-corporations. Viacom, Time Warner, News Corp, Clear Channel and Disney all have separate divisions for the creation of TV shows, films, comics, and video games. These divisions allow media conglomerates to retain a percentage of the profits from each branch, rather than having to outsource such components to a competitor. Due to this horizontal integration, the entertainment industry has an incentive to produce content that moves fluidly across media sectors (Smith, 2009, p. 10).

As Smith notes, incumbents within the media production sphere have been able to adapt and hold on to their place of dominance by using transmedia storytelling. A small oligopoly of Hollywood production companies has dominated media production related to the motion

picture business for the last century (Silver, 2010). This is perhaps why the most visible and most commonly studied examples of transmedia 
storytelling in the literature are those undertaken by large companies, such as the major Hollywood studios. ${ }^{5}$

Those that do analyse low budget and niche styles of transmedia storytelling also describe it as a reaction to specific threats or opportunities apparent in a marketplace. Cunningham (2013) argues that smaller companies turn to transmedia storytelling because they are forced to innovate in order to remain competitive. Similarly, Scolari (2014) uses semio-narrative analysis to demonstrate that an independent retelling of Don Quixote represents a visible "new dimension" of transmedia storytelling, a successful project predicated on being a socio-cultural mirror of its surroundings. This directly reflects a core argument put forward by Porter about the strategies of small businesses:

Unlike the giants, small businesses cannot rely on the inertia of the marketplace for their survival. Nor can they succeed by brute force, throwing resources at problems. On the contrary, they have to see their competitive environment with particular clarity, and they have to stake out and protect a position they can defend (Porter, 1991, p. 1).

This shows that these strategic ideas are directly relevant in forming a framework for analysing how and why different organisations choose transmedia storytelling, regardless of if they are large or small.

Porter's generic strategies for competitive advantage also provide a framework for direct comparison of transmedia strategies. Porter (1991) argues that competitive advantage can be attained using three generic strategies: 1) differentiation to a mass audience, 2) cost leadership (i.e. low cost) to a mass market or 3 ) focus -targeting specific market segments/ audiences and within that segment using either differentiation or cost leadership to a niche audience.

You can have consistently lower costs than your rivals [...] Alternatively, you can differentiate your product or service from your competitors', in effect making yourself unique at delivering something your customers think is important. That allows you to command a premium price (Porter, 1991, § 20).

5 In the business sphere this is referred to as incumbent advantage, with many companies sustaining their dominance of an industry by using their size and resources to reach a broad audience at a level of cost and quality their competitors cannot hope to match (Bain, 1954; Hearn \& Pace, 2006). 
Referencing his earlier research on generic strategies for competitive advantage, Porter's article Know Your Place puts forward the following framework, Figure 2, for comparing the strategic decisions of different organisations. In particular, he links smaller independent companies to a narrow competitive scope, with their strategies specifically catered towards niche audience targets, and large companies to a broad target audience.

Figure 2. Porter's Generic Strategies

\section{Competitive Advantage}

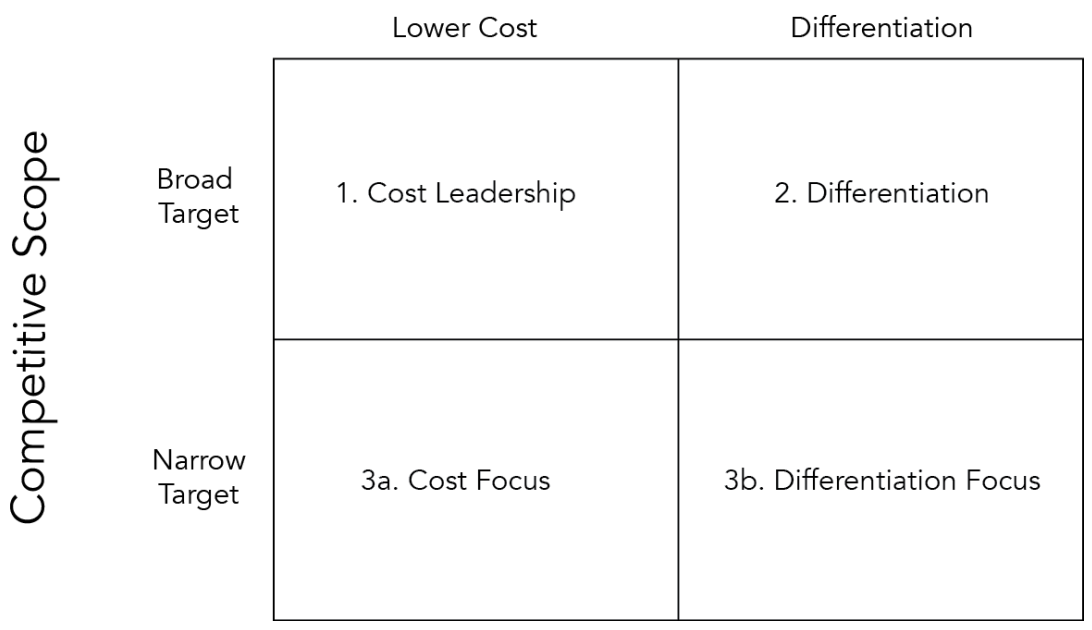

Source: Diagram from the University of Cambridge (2015), reproduced from pp. 11-15 of Porter (1985), Competitive Advantage. Creating and Sustaining Superior Performance. New York, NY: Free Press.

As Figure 2 illustrates, the scope of a company's target audience or marketplace combines with the focus of a company's activities, allowing for an analyst to assess three generic strategies: differentiation, cost leadership and focus.

1 Differentiation refers to a firm seeking to compete by being unique to its buyers.

a. Uniqueness is often used to command a premium price by appealing to one or more aspects of a product that the customers of 
that industry perceive as important. True differentiation establishes a position that is very difficult to replicate and thus generates sustained competitive advantage (Porter, 1985).

b. This is commonly seen in Hollywood franchises as they use stars, visual effects and scales of production that their smaller competitors simply cannot hope to afford (Silver, 2010).

2 Cost leadership refers to a firm becoming the leader of its industry based on lower operational costs than its competitors.

a. This can refer to economies of scale, proprietary technology, access to raw materials -anything that produces a sustainable advantage through a superior return on investment for the firm (Porter, 1985). b. When combined with the common idea of lowering barriers to entry within transmedia research (Phillips, 2012; Pratten, 2011; Wang \& Singhal, 2016), this also extends to lowering the cost of audiences in engaging with the story world by making access more convenient, immediate or personalised for the audience.

3 Focus refers to a company either;

a. seeking to compete in a niche market segment by providing a lower cost product that represents good value

b. seeking to differentiate their product from others in a niche market, either servicing an unusual need or creating superior value in a different way e.g. a delivery system that best serves that market (Porter, 1985).

Each of these categories, when considered alongside existing transmedia research, provides the first step for cross-analysing transmedia storytelling strategies.

\section{Step 2: Strategic Implementation and Audience Engagement}

Beyond objectives and external considerations, Porter also provides a methodology for analysing the implementation of strategies themselves. His article What is Strategy? breaks the analysis of strategy into three segments: defining a company's unique position, trade-offs and strategic fit (Porter, 1996). These segments then drive the success of a strategy-its ability to achieve competitive advantage. This section combines these elements with transmedia storytelling audience engagement research to form the second step in analysing transmedia storytelling strategies. 
Unique positioning means delivering "a unique mix of value [...] Choosing to perform activities differently or to perform different activities to rivals" (Porter, 1996, p. 64). It involves linking together the value proposition (what the company or organisation is providing for its audience) and the value chain (how the company or organisation coordinates its resources to create the maximum value for that audience (Magretta, 2012). ${ }^{6}$ This can be seen in how transmedia researchers talk about the way media platforms are leveraged to engage an audience. Leveraging a unique mix of media platforms to tell a narrative provides an audience with new forms of engagement that keep them interested, engaged and entertained (Alexander, 2011). Some experiences are designed so that they preference entertainment and immersion, while others focus on different aspects like social connection, mastery and self-efficacy (Askwith, 2007). It is how audience attention is directed through and across story modes that makes each transmedia strategy unique (Scolari, 2013), and this pursuit of unique positioning through engagement provides a strong point of comparison between different approaches.

Trade-offs refer to the necessary sacrifices that a company or firm intentionally makes to create their unique position and ensure its sustainability. A unique position cannot be attained without actively making trade-offs that forgo the advantages of another position (Porter, 1996). This is reflected in how transmedia scholars such as Dena (2008) and Evans (2008) divide audience segments into three tiers:

1 Low: $85 \%$ of the audience form a passively engaged or time poor portion who will not experience all that the producers have created.

2 Medium: $10 \%$ will be moderately engaged and create some word of mouth about the project, driving some of their own interaction.

3 High: 5\% will actively seek out all story modes, foster social connections with other audience members because of this narrative world and interact at every opportunity.

A transmedia producer cannot design an experience, especially on a low budget, that focusses on engaging all tiers at once to the same degree

6 Magretta writes specifically about Porter's relevance to contemporary business practices, showing that these particular advances on strategy, while now two decades old, still underpin the majority of business thinking today. She argues that those who content with Porter about these elements of strategy are often actually expanding upon his ideals rather than proving any logical inconsistencies. 
(Phillips, 2012). They must make concessions in time, money, autonomy or ease of use in order to sustain the engagement of audiences ${ }^{7}$ with different expectations for their engagement (Dena, 2008). Therefore, each project contains certain trade-offs in the way it seeks to engage its audience, trade-offs that are linked to their guiding strategy and the context in which they operate.

Strategic Fit, the final component, stipulates that strategy is about combining activities. "Fit locks out competitors by creating a chain that is as strong as its strongest link" (Porter, 1996, p. 70). It is broken into three tiers:

1 Simple consistency between activities and overall strategy.

2 Each activity reinforcing other activities.

3 Optimisation of effort.

This component directly reflects one of the core tenants of transmedia storytelling, the idea of a whole being created that is greater than the sum of its parts (Gambarato, 2012). Transmedia storytelling is concerned not only with separate stories that form part of a larger world, but with creating a web of what Higgins (2001) termed as intermedia, the meaning generated between different points of interaction, by the way in which those points are arranged together. For example, in The Li:zie Bennet Diaries, a character removing itself from social media and, in effect, not posting any content for a while, adds more story through the arrangement of media rather than the creation of any new content (Whyte, 2013). When one character was shamed for sexual promiscuity within the narrative world, she posted less online, engaged with other characters less and her online playlists changed to reflect her struggle (J. Bushman, personal communication, August 24, 2015). In this way, we can use strategic fit to compare how different projects arrange their stories so that they form a cohesive world that engages audiences with an expanding and cohesive experience.

When these three components are considered together they provide a framework for analysing the strategic implementation of transmedia stories. This, in combination with Step 1, allows for an analysis for why

7 Particularly relevant to contemporary storytelling, is a consideration for the immediacy of different story modes available and how that impacts on the audience's experience (Bostan \& Marsh, 2012). 
producers choose certain strategies, how it is related to their individual contexts and what advantage those strategies give their projects in the marketplace.

The next section put this framework into action, showcasing how low-budget, independent storytellers took advantage of their production contexts and produced unique transmedia storytelling strategies that provided them with substantial competitive advantage. The text in question is one of digital transmedia storytelling's earliest successes, Sofia's Diary.

\title{
Sofia's Diary
}

\author{
People don't buy content, people buy \\ experience, people buy context. \\ N. Bernardo
}

Diário de Sofia (Sofia's Diary) was a low-budget, independent and experimental project that originated in Portugal in 2003. Created by author and producer Nuno Bernardo, it is regarded as one of the earliest success stories from the pioneering years of digital transmedia storytelling (Gambarato, 2012). A projected designed for teenage school-girls in Portugal, it used multiple low-cost media platforms to relay the daily struggles of Sofia as she went through elementary school. The first iteration of the project was a runaway success, with over 200000 monthly visitors to the blog, 19,000 mobile subscribers and 4 seasons on a state television broadcaster RTP2 (Stack, 2008). It also sold over 500,000 books in a country of just 10 million people and, in the coming years would be reproduced in over 30 territories and adapted into 10 different languages (Bernardo, 2011a). Sofia's Diary achieved all of this success in a manner that differed fundamentally from the big-budget, global distribution and market saturation tactics of narrative franchises like Lego or The Marvel Cinematic Universe (Zeiser, 2015). As this case study demonstrates, it was through a niche, cost-focussed and iterative use of transmedia storytelling that Sofia's Diary found its success.

\section{Context \& Objectives}

When Sofia's Diary began in 2003, most of the television programming available to teenage girls in Portugal was not aimed at them, consisting 
instead of a saturation of adult soap opera. Bernardo realised this while he conducted research working for another company. His research indicated that there was also a lack of storytelling content on the platforms that school girls were using; namely mobile phones, radio (in the car), and web blogs (N. Bernardo, personal communication, October 13, 2015).

The reason we wanted to do a teen diary was because, at the time of course we needed to make some money and we needed to make this a very commercial experience. At the time, I wrote some studies and the studies said that the big consumers of mobile entertainment, the ones who were really paying for content, were teenage girls. They were not paying for music, they were not paying for videos, because they're downloading it illegally. But they were paying for ring tones, for the cute bears for wallpaper for their phone... people don't buy content, people buy experience, people buy context (N. Bernardo, personal communication, October 13, 2015).

For these reasons, the project was initially pitched to local Portuguese networks as a television show with interactive phone and online components that would make the audience feel like they were a part of Sofia's life. However, despite positive feedback from the network, Sofia's Diary was rejected because these platforms were untested. The network deemed it too risky and lacked confidence that it was a financially viable project due to its non-traditional and unusual multiplatform approach (Bernardo, 2011b).

As it was their first project, this left beActive (Bernardo's company) with a tension between a contextual opportunity and their own objectives. At the time when Sofia's Diary was conceived (and arguably still today), independents in the European market and in particular in Portugal, generally relied upon traditional financing approaches to make the majority of screen content (Miller, 2014).

Unlike Hollywood studios, European independents must generate a production model on a project-by-project basis because they can only produce the film if they get funding from third parties. When they do receive backing and produce a film, they must reassign almost all of their works' rights to external companies in order to facilitate the distribution and marketing of their work (Bernardo, 2014, p. 18). 
The problem facing Bernardo's production company was that relying on a traditional approach to financing projects would leave them without the control, revenue or sustainability that came from funding their own intellectual property. To create narrative content with this model, an independent production company such as Bernardo's faced a constant reliance on the input of others (Bernardo, 2015). beActive Entertainment needed to find a sustainable source of revenue and to avoid direct competition with larger companies who could easily bully them out of contention with better resources.

\section{Unique Position}

When a company generates "blue oceans" or "uncontested spaces where the competition is irrelevant [...] you invent or capture new demand", they are able to achieve a unique competitive advantage (Kim \& Mauborgne, 2013, p. 124). ${ }^{8}$ In blue ocean strategy, rather than competing in an existing market or "red ocean", a company focusses upon creating value in a way that previously did not exist. This type of approach can be used to explain why beActive used transmedia storytelling strategy, as it provided them with a unique position and a blue ocean for Sofia's Diary.

Learning from their initial failure to find traditional pathways for the project, beActive adapted their project and self-invested in the minimum amount that they needed to get the project noticed. Focussing on text messaging and an online blog, beActive refocussed and launched their experience as a game. A press release from the project's launch proclaims,

This game, never seen before in Portugal, gives the participants the power to 'decide' Sofia's daily actions: if she will go to a lesson or not, if she accepts her boyfriend's request, making new friends, introducing or expelling a character, and many other decisions (beActive, n. d).

8 A core example of this that they use is that of the famous entertainment company Cirque De Soleil. More than a decade ago, Cirque De Soleil exploded into a global force by generating their own market. Instead of using the expensive animal acts of a circus or the dialogue dependent storylines of traditional theatre, they blended acrobatics and showmanship with music and mime, creating a new market that was not quite theatre or circus and directly competed with neither (Kim \& Mauborgne, 2013). While some consider these strategies directly contradictory to the warlike grounding of Porter's notions of competitive strategy, Magretta (2012) reminds us that to do so is a fallacy born from a lack of interrogation of Porter's work over time. Porter's strategy evolved to become essentially about the pursuit of uniqueness, rather than competition, an ideal of Kim and Mauborgne's blue ocean ideals. 
As the interactive hints within this press release indicate, from the beginning, beActive emphasised social connection with Sofia's Diary. Creating the project as a transmedia narrative was a deliberate strategic choice by beActive so that audience members would feel like they were one of Sofia's friends (N. Bernardo, personal communication, October 13, 2015).

From its initial "game" roots, the project developed into a narrative that was deliberately and strategically spread across different platforms so that it mirrored the way that its target audience, teenage girls, were actually using media in their daily lives (N. Bernardo, personal communication, October 13, 2015). As the popularity of Sofia's Diary grew online among teenage girls, the producers employed a publicity stunt to cast the face of Sofia ${ }^{9}$ hoping to stimulate further interest in the program. The casting announcement resulted in thousands of teens lining up around a city block hoping to become the face of the project, and television studios that had originally rejected Bernardo's concept ${ }^{10}$ approached beActive to make a television component. Soon audiences could also watch daily 5 minute shows after school that continued the narrative of Sofia's Diary (Miller, 2014). Fans could even read a column in a teen magazine once a month that summarised how Sofia was going or buy books that recapped each season of the show.

This structure is indicative of effective strategic fit, one of the core underlying aspects of competitive advantage within Porter's model. Using low cost, fragmented and interlinked media components, Bernardo told the single narrative of Sofia's life. This is what Pratten (2011) and Gambarato (2012a; 2012b) describe as a 'portmanteau' transmedia story. Rather than seeking long-term engagement with individual story modes, Sofia's Diary used different story modes to provide alternate perspectives (such as the books and online blogs), ${ }^{11}$ methods of interaction (active

9 A publicity strategy that can be traced back to producer David Selznick in 1937-38 to cast the role of Scarlett O'Hara in Gone with the Wind (Bridges \& Boodman, 1989, pp. 212-229).

10 Their reception was positive but they could not commit to financing the story due to uncertainty over financial returns from this untested format.

11 The books provided two forms of alternate perspective. In the series penned from the perspective of the main character, Sofia they helped to provide additional information from her point of view on events that had already happened. In another series, they reimagined events from the perspective of her younger sister, still covering the same single narrative but from a different perspective. Additional perspective is something that Jenkins recognises as part of transmedia storytelling's power to provide independent but interlinked story modes that further a narrative world and an audience's engagement of that world (Jenkins, 2007). 
discussion and SMS interactions and passive television viewing) and new pieces of information (radio, television and SMS). These elements worked holistically together, adding different dimensions to the single narrative of Sofia's daily dilemmas.

Because of this effective strategic fit, beActive achieved a unique position in the marketplace in the following ways:

- They became a non-competitive, investment opportunity for their formal rivals, creating tailored content that filled gaps in their programming.

- Rather than competing with larger productions on any one format, they used small bursts through each media channel to gain a spot in the market.

- They turned a regional, non-English speaking marketplace (Portugal) into a competitive advantage.

- Through their trial and error, they created an ongoing revenue stream in format sales in other regional areas and larger Englishspeaking markets. ${ }^{12}$

- Their format of analysing young women in a region and holding up a mirror to their daily experiences through a socially connected narrative and a strong female lead became an ongoing source of passive income that helped to sustain beActive and generate further projects.

- They focussed on lowering barriers to entry for their audience and thus the physical and emotional cost of engaging with their narrative for that audience.

These elements of unique positioning show that the project reflects Porter's notion of narrow, cost leadership strategy (3a in Figure 2). The project was created for a specific audience and, as the project grew, each stage saw the producers return to how they could engage audiences in a convenient, native manner for the audiences. Each additional channel was also only added when a partnership deal was struck with a channel

12 A format, language most often used in the television production space, refers to a particular structure for telling a story. Producers control the intellectual property relating to how their story is told, even when it is dispersed across multiple platforms and this allows them to license or sell that format to other production companies who wish to use that structure (Bachmayer, Lugmayr, \& Kotsis, 2010). 
specific investor (Bernardo, 2011b). However, this unique position did not come without substantial trade-offs;

- A reliance upon a small number of highly engaged audience members to drive the involvement of the wider public at the start of the project.

- As is detailed in Cliff (2012; 2017), Hollywood projects tend to rely upon a broad reach to generate a cycle of engagement that then draws in highly connected audience members and rewards their participation.

- Sofia's Diary was a finite concept. This is what allowed it to be packaged and resold. However, following the growing up story of a teenager and tapping in to that market meant giving up the never ending dream or "evergreen" aspirations of traditional Hollywood transmedia (J. Gomez, personal communication, September 17, 2015).

- Upfront investment meant a period of uncertainty and the potential for significant loss in a trade-off for retaining intellectual property control and long-term revenue from the project.

- As the project grew, Bernardo also had to allow for less audience interactivity with the development of the narrative world, something that had been a mainstay of the early portions of Sofia's Diary.

- In his interview, he noted that real interaction had to give way to the illusion of conversation and choice, something that Bernardo linked to the style of transmedia strategy becoming more like that of a Hollywood studio as the project grew (N. Bernardo, personal communication, October 13, 2015).

Each of these trade-offs represented a point of choice for the producers of Sofia's Diary. In making these choices, beActive chose to apply transmedia storytelling in a manner vastly different from a large 'Hollywood' studio rather than competing with that sort of content in a smaller arena. By using a cost-leadership strategy for a niche audience, Sofia's Diary became an enduring example of a successful, independent transmedia storytelling strategy. 


\section{Conclusion}

Sofia's Diary is just one example of how strategic thinking can be used to pierce semantic chaos and bring together existing research to understand the relevance and effectiveness of transmedia storytelling. There are transmedia stories across each of Porter's four generic strategy quadrants. ${ }^{13}$ Additionally, Porter is just one of many competitive advantage theorists with models that can help to unify transmedia thinking. As this brief case study of Sofia's Diary demonstrates, strategic thinking is a viable and effective tool for bringing multiple disciplines to bear on innovative projects. Further in depth analysis can be undertaken by applying tools like semio-narrative analysis from media culture (Ibrus \& Scolari, 2014), audience engagement analysis from fan behaviour studies (Askwith, 2007), frameworks for inciting longevity of engagement with story from advertising (Andrews, Durvasula, \& Akhter, 1990). However, until further studies can be conducted, this case study shows that transmedia storytelling does have direct relevance to creative practice, especially if we use strategic thinking to establish the goals, contexts and objectives of producers who are telling their stories.

13 The Marvel Cinematic Universe as broadly focussed differentiation, Doctor Who as broadly focussed cost-leadership and The Lizieie Bennet Diaries as narrow differentiation to name a few. 


\section{Appendix A. Methods and ontological perspectives of Transmedia storytelling}

\begin{tabular}{|c|c|c|}
\hline Approach & Key Source & Summary \\
\hline Adaptation & $\begin{array}{l}\text { (Dena, 2009; } \\
\text { Smith, 2009) }\end{array}$ & $\begin{array}{l}\text { Creating another version of a narrative in a } \\
\text { form different from the original. E.g. adapting } \\
\text { a book into a transmedia storytelling form } \\
\text { for example Pride and Prejudice became The } \\
\text { Lizzie Bennett Diaries on YouTube and other } \\
\text { platforms. }\end{array}$ \\
\hline $\begin{array}{c}\text { Augmented } \\
\text { Reality Games }\end{array}$ & (Abba, 2009) & $\begin{array}{l}\text { Audience members must transverse platforms } \\
\text { to make sense of the story, piecing together } \\
\text { a single narrative from multiple pieces } \\
\text { scattered across different platforms. }\end{array}$ \\
\hline Cross-media & (Mungioli, 2011) & $\begin{array}{l}\text { A term often used interchangeably with } \\
\text { transmedia, especially in European circles. It } \\
\text { can, however, be used as an umbrella term in } \\
\text { the same fashion as multiplatform storytelling. }\end{array}$ \\
\hline Distinct Media & (Dena, 2009) & $\begin{array}{l}\text { Distinct media is a term that Dena coins to } \\
\text { refer to the specifically crafted individual } \\
\text { media platforms that all are part of a } \\
\text { storytelling practice. }\end{array}$ \\
\hline $\begin{array}{l}\text { Distributed } \\
\text { Narrative }\end{array}$ & (Walker, 2004) & $\begin{array}{l}\text { "Distributed narratives are stories that aren't } \\
\text { self-contained. They're stories that can't be } \\
\text { experienced in a single session or in a single } \\
\text { space. They're stories that cross over into } \\
\text { our daily lives, becoming as ubiquitous as the } \\
\text { network that fosters them" (p. 2). }\end{array}$ \\
\hline $\begin{array}{l}\text { Entertainment } \\
\text { Architecture } \\
\text { (Entarch) }\end{array}$ & $\begin{array}{c}\text { (Konzal, 2011; } \\
\text { 2012) }\end{array}$ & $\begin{array}{l}\text { A sub-strategy of transmedia storytelling that } \\
\text { refers to a web-native, specifically interactive } \\
\text { form of entertainment. }\end{array}$ \\
\hline Intermedia & (Higgins, 2001) & $\begin{array}{l}\text { This refers to the imaginative space } \\
\text { constructed by audiences "between media". } \\
\text { Intermedia is the construct, the emotions } \\
\text { and the experiences that people have when } \\
\text { various media are combined. }\end{array}$ \\
\hline $\begin{array}{l}\text { Multimodal } \\
\text { Narratives }\end{array}$ & (Ruppel, 2009) & $\begin{array}{l}\text { Used to describe stories told through } \\
\text { sequential and causal distribution of story } \\
\text { "modes" or components. }\end{array}$ \\
\hline
\end{tabular}




\begin{tabular}{|c|c|c|}
\hline Approach & Key Source & Summary \\
\hline $\begin{array}{l}\text { Multiplatform } \\
\text { Storytelling }\end{array}$ & (Bolin, 2007, 2010) & $\begin{array}{l}\text { Similar to transmedia storytelling except } \\
\text { these narrative do not necessarily contain } \\
\text { independent narrative extensions. This can } \\
\text { be seen as a larger parent term within which } \\
\text { transmedia storytelling operates. }\end{array}$ \\
\hline Multimedia & (Dena, 2009) & $\begin{array}{l}\text { "Multimedia is a terribly polysemous term, } \\
\text { it is invoked here rhetorically to denote } \\
\text { the conventional association with a mix of } \\
\text { text, images, video and sound. The problem } \\
\text { with this notion of multimedia is that it is } \\
\text { often regarded as being representative of } \\
\text { all expressive possibilities, yet is oblivious } \\
\text { to other medial factors such as the delivery } \\
\text { medium" (p. 4). }\end{array}$ \\
\hline $\begin{array}{l}\text { Serialised } \\
\text { Narrative }\end{array}$ & (Jenkins, 2010) & $\begin{array}{l}\text { Most often applied to television narratives, } \\
\text { this refers to stories told one after another } \\
\text { that rely upon the narrative contained in the } \\
\text { text released chronologically before them to } \\
\text { make sense. }\end{array}$ \\
\hline Transmedia & $\begin{array}{c}\text { (Dena, 2009; } \\
\text { Jenkins, 2006) }\end{array}$ & $\begin{array}{l}\text { A larger umbrella term for a mix of media } \\
\text { platforms that work together to form } \\
\text { something. This can apply to branding, } \\
\text { fictional and factual storytelling, activism, } \\
\text { franchising, business models, education and } \\
\text { marketing. }\end{array}$ \\
\hline $\begin{array}{l}\text { Transmedia } \\
\text { Practice }\end{array}$ & (Dena, 2009) & $\begin{array}{l}\text { "The theory of transmedia practice examines } \\
\text { a creative practice that involves the } \\
\text { employment of multiple distinct media and } \\
\text { environments for expression" (p. 1). }\end{array}$ \\
\hline $\begin{array}{l}\text { Transmedia } \\
\text { Storytelling }\end{array}$ & (Jenkins, 2011) & $\begin{array}{l}\text { A narrative or narrative world told through } \\
\text { multiple unique but interlinked media } \\
\text { platforms. Ideally each platform is its } \\
\text { independent, with little to no replication of } \\
\text { other platforms. }\end{array}$ \\
\hline
\end{tabular}

Source: Cliff (2017, p. 200). 


\section{References}

Aaker, D. A. (1998). Strategic Market Management. University of Berkley, CA: John Wiley \& Sons.

Abba, T. (2009). Hybrid Stories: Examining the Future of the Transmedia Narrative. Journal of Science Fiction Film and Television, 2(1), 59-75. Available in https://bit.ly/2STcABe

Alexander, B. (2011). The New Digital Storytelling: Creating Narratives with New Media. Santa Barbara, CA: Praeger.

Andrews, J. C., Durvasula, S., \& Akhter, S. H. (1990). A Framework for Conceptualizing and Measuring the Involvement Construct in Advertising Research. Journal of Advertising, 19(4), 27-40. Retrieved from https://bit.ly/2ArV5B5

Askwith, I. (2007). Television 2.0: Reconceptualizing TV as an Engagement Medium (Master's thesis). Massachusetts Institute of Technology, Boston, MA. Retrieved from https://bit.ly/2C291Sm

Bachmayer, S., Lugmayr, A., \& Kotsis, G. (2010). Convergence of collaborative web approaches and interactive TV program formats. International Journal of Web Information Systems, 6(1), 74-94. doi: https:// doi.org/10.1108/17440081011034493

Bain, J. S. (1954). Conditions of Entry and the Emergence of Monopoly BT - Monopoly and Competition and their Regulation. In Monopoly and Competition and their Regulation (pp. 215-241). London, England: Palgrave Macmillan UK.

Barney, J. B., \& Clark, D. N. (2007). Creating and Sustaining Competitive Advantage. Creating and Sustaining Competitive Advantage. Oxford, MA: Oxford University Press.

BeActive. (n. d.). Sofia is Born!

Bernardo, N. (2011a). The Producer's Guide to Transmedia Storytelling. How to Develop, Fund, Produce and Distribute Compelling Stories Across Multiple Platforms. Dublin, Ireland: BeActive Books. 
Bernardo, N. (2011b, November 23). Nuno Bernardo: Financing Transmedia. Mipblog.com. Retrieved from https://bit.ly/2SNrnNO Bernardo, N. (2014). Transmedia 2.0. Lisbon, Portugal: BeActive Books. Bernardo, N. (2015, November 23). Social Storytelling: Not all Fans are born equal! Nunobernardo.com. Retrieved from https://bit.ly/2LU2u0w Bolin, G. (2007). Media Technologies, Transmedia Storytelling and Commodification. In T. Storsul \& D. Stuedahl (Eds.), Ambivalence towards convergence: digitalization and media change (pp. 237-248). Göteborg, Sweden: Nordicom. Available in https://bit.ly/2FlvoFu

Bolin, G. (2010). Digitization, Multiplatform Texts, and Audience Reception. Popular Communication, 8(1), 72-83. Available in https://bit. ly/2REGfAN

Bostan, B., \& Marsh, T. (2012). Fundamentals of Interactive Storytelling. Online Academic Journal of Information Technology, 3(8), 19-42. doi: 10.5824/1309-1581.2012.3.002.x

Bressler, M. S. (2012). How small businesses master the art of competition through superior competitive advantage. Journal of Management and Marketing Research, (11), 1-12. Retrieved from https://bit.ly/2TEFTYD Bridges, H., \& Boodman, T. C. (1989). Gone with the Wind: The Definitive Illustrated History of the Book, the Movie and the Legend. New York, NY: Simon \& Shuster.

Clark, B. (2012, April 21). Transmedia is a Lie. Facebook.com. Retrieved from https://bit.ly/2IUeTza

Cliff, Cameron R. (2012). Transmedia New Product Development: A New Model for Audience Engagement and Developing Transmedia Projects (Master's Honours thesis), Queensland University of Technology, Brisbane, Australia.

Cliff, Cameron R. (2017). Transmedia Storytellng Strategy: How and Why Producers Use Transmedia Storytelling for Competitive Advantage (Doctoral thesis). Queensland University of Technology, Brisbane, Australia. Available in https://bit.ly/2CFHdEI

Collis, D. J., \& Montgomery, C. A. (1998). Creating Corporate Advantage. Harvard Business Review, 76(3), 70-83. Retrieved from https://bit. ly/2CUv6E1 
Cunningham, S. (2013). Hidden Innovation: Policy, Industry and the Creative Sector. Policy, Industry and the Creative Sector. Brisbane, Australia: University of Queensland Press.

Cunningham, S., Silver, J., \& McDonnell, J. (2010, August). Rates of change: online distribution as disruptive technology in the film industry. Media International Australia, 136(1), 119-132. Retrieved from https:// bit.ly/2M58u6s

Dena, C. (2008). Emerging Participatory Culture Practices: PlayerCreated Tiers in Alternate Reality Games. Convergence: The International Journal of Research into New Media Technologies, 14(1), 41-57. doi: https:// doi.org/10.1177/1354856507084418

Dena, C. (2009). Transmedia Practice: Theorising the Practice of Expressing a Fictional World across Distinct Media and Environments (Doctoral thesis). University of Sydney, Australia. Retrieved from https://bit.ly/2zGttbX Dena, C. (2014). Transmedia as "Unmixed Media" Aesthetics. In D. Polson, A-M. Cook, J. T. Velikovsky, \& A. Brackin (Eds.), Transmedia Practice: A Collective Approach (pp. 3-16). Oxford, England: Inter-Disciplinary Press.

Deuze, M. (2010). Managing Media Work. Reference and Research Book News (Vol. 25). Portland, OR: SAGE.

Evans, E. (2008). Character, audience agency and transmedia drama. Media, Culture \&o Society, 30(2), 197-213. doi: https://doi. org/10.1177/0163443707086861

Evans, E. (2011). Transmedia Television: Audiences, New Media, and Daily Life. New York, NY: Routledge.

Falzon, C. (2012). Brand Development and Transmedia Production. Journalism and Mass Communication, 2(9), 925-938. Retrieved from https:// bit.ly/2C6ojW2

Fast, K., \& Örnebring, H. (2015). Transmedia world-building: The Shadow (1931-present) and Transformers (1984-present). International Journal of Gultural Studies, 20(6), 636-652. doi: https://doi. org/10.1177/1367877915605887

Gambarato, R. R. (2012a). How to Analyze Transmedia Narratives? BT - Baltic Film and Media School Screen Studies. In Baltic Film and 
Media School Screen Studies. Tallinn, Estonia: Tallinn University Press. Retrieved from https://bit.ly/2TAxo0G

Gambarato, R. R. (2012b). Signs, systems and complexity in transmedia storytelling. Estudos Em Comunicação, (12), 69-83. Retrieved from https://bit.ly/2VzzVtO

Hadas, L. (2014). Authorship and Authenticity in the Transmedia Brand: The Case of Marvel's Agents of S.H.I.E.L.D. Networking Knowledge, 7(1), 7-17. doi: https://doi.org/10.31165/nk.2014.71.332

Hamel, G., \& Prahalad, C. K. (1989). Strategic Intent. Harvard Business Review, 67(3), 63-78. Retrieved from https://bit.ly/21dNTyN

Hardy, J. (2011). Mapping commercial intertextuality: HBO's True Blood. Convergence: The International Journal of Research into New Media Technologies, 17(1), 7-17. doi: https://doi.org/10.1177/1354856510383359 Hearn, G., \& Pace, C. (2006). Value-creating ecologies: understanding next generation business systems. Foresight, 8(1), 55-65. doi: https://doi. org/10.1108/14636680610647147

Higgins, D. (2001). Intermedia. LEONARDO, 34(1), 49-54. Retrieved from https://bit.ly/2CS7HTu

Holt, J., \& Sanson, K. (2014). Connected Viewing: Selling, Streaming 8 Sharing Media in the Digital Age. New York, NY: Routledge.

Hsu, W., \& Shih, S. (2013). From hybrid TV towards transmedia: Recent marketing advances of the New Media developments. In 24th European Regional Conference of the International Telecommunication Society, Florence, Italy, October 20-23, 2013. Retrieved from https://bit.ly/2FhdlAf Ibrus, I., \& Scolari, C. A. (2014). Transmedia Critical: Empirical Investigations into Multiplatform and Collaborative Storytelling. International Journal of Communication, 8, 2191-2200. Retrieved from https:// bit.ly/2C6vE82

Jenkins, H. (2003, January 15). Transmedia Storytelling. MIT Technology Review [on line]. Retrieved from http://bit.ly/22v1yRK Jenkins, H. (2006). Convergence Culture: Where Old and New Media Collide. New York, NY: New York University Press.

Jenkins, H. (2007, March 22). Transmedia Storytelling 101. Confessions of an Aca-Fan: The Official Weblog of Henry Jenkins. Retrieved from https://bit.ly/2wpzJzy 
Jenkins, H. (2010). Transmedia Storytelling and Entertainment. Continuum: Journal of Media \&̊ Cultural Studies, 24(6), 943-958. doi: https:// doi.org/10.1080/10304312.2010.510599

Jenkins, H. (2011, July 31). Transmedia 202: Further Reflections. Confessions of an Aca-Fan: The Official Weblog of Henry Jenkins. Retrieved from https://bit.ly/1pQHLfh

Jenkins, H. (2012, January 1). How to Ride a Lion: A Call fo Higher Transmedia Criticism (Part One). Confessions of an Aca-Fan: The Official Weblog of Henry Jenkins. Retrieved from https://bit.ly/2AtsJ9B Johnson, D. (2012, December 17). A History of Transmedia Entertainment. Spreadable Media. Retrieved from https://bit.ly/2H8wlUm Kim, W. C., \& Mauborgne, R. (2013). Blue Ocean Strategy: How to Create Uncontested Market Space and Make the Competition Irrelevant. Boston, MA: Harvard Business Review Press.

Kinder, M. (1991). Playing with Power in Movies, Television, and Video Games: from Muppet Babies to Teenage Mutant Ninja Turtles. Berkeley, CA: University of California Press.

Konzal, A. W. (2011). Entertainment Architecture: Constructing a Framework for the Creation of an Emerging Transmedia Form. ARC Centre for Excellence for Creative Industries and Innovation (Doctoral thesis). Queensland University of Technology, Brisbane. Australia. Retrieved from https://bit.ly/2sIVvUU Konzal, A. W. (2012). Entertainment Architecture: Constructing a Framework for the Creation of an Emerging Transmedia Form. Cultural Science, 5(2), 120-152. Retrieved from https://bit.ly/2RDhOnC

Livingstone, A., Mckenny, M., \& Flanagan, M. (2017). The Marvel Studios Phenomenon. New York, NY: Bloomsbury.

Long, G. (2007, June 24). Transmedia Storytelling: Business Aesthetics and Production at the Jim Henson Company (Master's thesis). Massachusetts Institute of Technology, Boston, MA. Retrieved from https://bit.ly/2F9uHQg Magretta, J. (2012). Understanding Michael Porter: The Essential Guide to Competition and Strategy. Boston, MA: Harvard Business Review Press. Miller, C. H. (2014). Digital Storytelling. A Creator's Guide to Interactive Entertainment (3rd ed.). Burlington, MA: Focal Press.

Mungioli, M. C. (2011). Narratives, languages and media in the context of interactive digital technologies. Interview with Carlos Alberto 
Escolari. Matrizes, 4(2), 127-136. Retrieved from https://bit.ly/2Hd9p6q Norrington, A. (2010). Harnessing "e" in Storyworlds: Engage, Enhance, Experience, Entertain. Publishing Research Quarterly, 26(2), 96-105. doi: 10.1007/s12109-010-9161-8

Phillips, A. (2012). A Creator's Guide to Transmedia Storytelling. How to Captivate and Engage Audiences Across Multiple Platforms. New York, NY: McGraw-Hill.

Porter, M. (1985). Competitive Advantage. Creating and Sustaining Superior Performance. New York, NY: Free Press.

Porter, M. (1991, September 1). Know Your Place. Inc., 13(9). Retrieved from https://bit.ly/2RcxIWH

Porter, M. (1996). What Is Strategy? Harvard Business Review, 74(6), 61-78. Available in https://bit.ly/1HuMxoI

Pratten, R. (2011). Getting Started in Transmedia Storytelling. [CreateSpace Independent Publishing Platform]. Available in https://bit.ly/2p0QFwG Rosenbaum, D. I. (Ed.). (1998). Market Dominance: How Firms Gain, Hold, or Lose It and the Impact on Economic Performance. Westport, CT: Praeger. Ruppel, M. (2009). Narrative Convergence, Cross-Sited Productions and the Archival Dilemma. Convergence: The International Journal of Research into New Media Technologies, 15(3), 281-298. doi: https://doi. org/10.1177/1354856509105108

Scolari, C. A. (2009). Transmedia Storytelling: Implicit Consumers, Narrative Worlds, and Branding in Contemporary Media Production. International Journal of Communication, (3), 586-606. Retrieved from https://bit.ly/2SaZ8Zd

Scolari, C. A. (2013). Media Evolution: Emergence, Dominance, Survival and Extinction in the Media Ecology. International Journal of Communication, 7, 1418-1441. Retrieved from https://bit.ly/2Qrj2xD

Scolari, C. A. (2014). Transmedia Critical Don Quixote of La Mancha: Transmedia Storytelling in the Grey Zone. International Journal of Communication, 8, 2382-2405. Retrieved from https://bit.ly/2FfrDkR Silver, J. (2010). The first global entertainment company: Explaining Pathé's dominance in the pre-Hollywood film industry. Continuum: Journal of Media \& Cultural Studies, 24(6), 877-895. doi: https://doi.org/10.1080/10304312.2010.510598 
Sinnreich, A. (2007). Come Together, Right Now: We Know Something's Happening, But We Don't Know What It Is. International Journal of Communication, 1, 44-47. Retrieved from https://bit.ly/2TCw1P1

Smith, A. M. (2009). Transmedia Storytelling in Television 2.0: Strategies for Developing Television Narratives Across Media Platforms. Strategies for Developing Television Narratives Across Media Platforms (Master's thesis). Middlebury College, Vermont. Retrieved from https://bit.ly/2GXPS9W Stack, D. (2008, March 18). Scriptwriting in the UK: Sofia's Diary [web log comment]. Retrieved from https://bit.ly/2TDnHP3

Walker, J. (2004). Distributed Narrative: Telling Stories Across Networks. Paper presented at the Association of Internet Researchers 5th Annual Conference. Brighton, England. Retrieved from https://bit. ly/1uKW9U4

Wang, H., \& Singhal, A. (2016). East Los High: Transmedia Edutainment to Promote the Sexual and Reproductive Health of Young Latina/o Americans. American Journal of Public Health, 106(6), 1002-1010. doi: 10.2105/AJPH.2016.303072

Whitler, K., \& Morgan, N. A. (2017). Why CMOs Never Last and What to Do About It. Harvard Business Review, 95(4), 46-54. Available in https://bit.ly/2sOaIjj

Whyte, M. (2013, February 18). Exclusive Interview: "Lizzie Bennet Diaries" Transmedia Producer Jay Bushman talks the Streamys, the show, more. Hypable. Retrieved from https://bit.ly/2SHcYD4

Zeiser, A. (2015). Transmedia Marketing Case Studies: From Film and TV to Games and Digital Media. New York, NY: Focal Press. 